\title{
Characterization and Analysis of the Mortars in the Church of the Company of Jesus-Quito (Ecuador)
}

\author{
M. Lenin Lara ${ }^{1,2, *(1)}$, David Sanz-Arauz ${ }^{1}$, Sol López-Andrés ${ }^{3}$ and Inés del Pino ${ }^{4}$ \\ 1 Department of Construction and Architectural Technology, Polytechnic University of Madrid, \\ 28040 Madrid, Spain; david.sanz.arauz@upm.es \\ 2 School for the City, Landscape and Architecture, UIDE International University of Ecuador, Simón Bolívar Av. \\ Jorge Fernández Av., Quito 170411, Ecuador \\ 3 Mineralogy and Petrology Department, Complutense University of Madrid, 28040 Madrid, Spain; \\ antares@geo.ucm.es \\ 4 Faculty of Arts, Design and Architecture, Pontifical Catholic University of Ecuador, Quito 170411, Ecuador; \\ idelpinom@puce.edu.ec \\ * Correspondence: leninlara@hotmail.com; Tel.: +34-593-994384851
}

Citation: Lara, M.L.; Sanz-Arauz, D.;

López-Andrés, S.; Pino, I.d.

Characterization and Analysis of the Mortars in the Church of the Company of Jesus-Quito (Ecuador). Minerals 2021, 11, 781. https:// doi.org/10.3390/min11070781

Academic Editor: Anna Arizzi

Received: 31 May 2021

Accepted: 14 July 2021

Published: 19 July 2021

Publisher's Note: MDPI stays neutral with regard to jurisdictional claims in published maps and institutional affiliations.

Copyright: (c) 2021 by the authors. Licensee MDPI, Basel, Switzerland. This article is an open access article distributed under the terms and conditions of the Creative Commons Attribution (CC BY) license (https:// creativecommons.org/licenses/by/ $4.0 /)$.

\begin{abstract}
The Church of the Company of Jesus in Quito (1605-1765) is one of the most remarkable examples of colonial religious architecture on the World Heritage List. This church has multiple constructive phases and several interventions with no clear record of the entire architectural site, including the historical mortars. A total of 14 samples of coating mortars inside the central nave were taken, with the protocols suggested by the research team and a comparative sample of the architectural group that does not have intervention. The analysis presented in this paper focuses on mineralogical characterization, semi-quantitative analysis by $\mathrm{X}$-ray diffraction and scanning electron microscopy with microanalysis of the samples. The results showed the presence of volcanic aggregate lime and gypsum, used in lining mortars and joint mortars. Mineralogical and textural composition data have allowed the mortar samples to be relatively dated.
\end{abstract}

Keywords: lime mortars; gypsum mortars; mineralogy of historical mortars; quito cultural heritage; church of the company of jesus in quito

\section{Introduction}

Historic buildings evolve over time and reflect upwardly the transfer of constructive knowledge. Its value and historical importance oblige to study the use and application of antique and new lining mortars to consolidate masonry in heritage buildings. Quito, which was declared World Heritage by UNESCO in 1978 [1,2], has the better preserved historical centre of Latin America denominated the "Great Convent" [3]. It is bounded by 375.25 hectares with more than 4674 built properties of which 130 are monumental assets. In the 16th century, 15 religious buildings stood out in this colonized urban centre; this paper focuses on the Jesuitic complex (Figure 1) [4-6].

The best example of both the interpretation of hierophany and dominance of power after the conquest is the Church of the Company of Jesus in Quito, which fuses the prehispanic building tradition with the European technique. The church was built by following the architectural plan and guidelines brought from Gesú di Roma by the principal Nicolas Duran Mastrilli [7]. It denotes the practical example of the Latin American baroque built between 1605 and 1765: it has a single nave distribution, communicating chapels, and a transept connected with the north and south chapels, presbytery, and sacristy. The church is $58.855 \mathrm{~m}$ long and $26.585 \mathrm{~m}$ wide, the height of the vault of the central nave is $16.00 \mathrm{~m}$ and the larger diameter of the transept cupola is $10.60 \mathrm{~m}$, and the presbytery is $12.50 \mathrm{~m}$ long by $9.00 \mathrm{~m}$ wide [8-10]. 


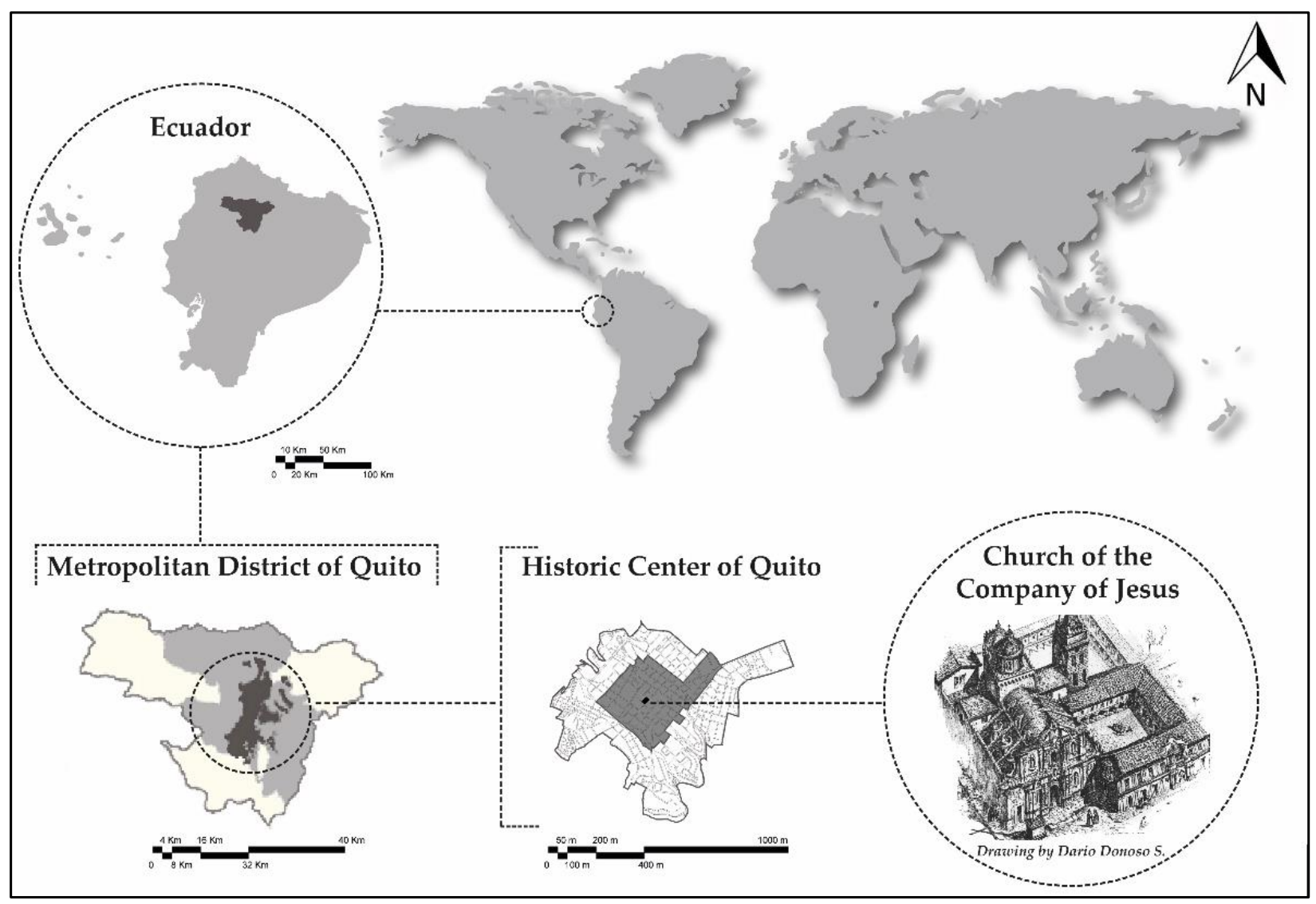

Figure 1. Location and context of the study area, and the drawing by Dario Donoso Samaniego included in page 57 [11].

The architectural transformation of the churches in Quito between the 17th and 19th centuries was complex due to the events that took place over time, thus making the reading or the analysis of the constructive phases and procedures something of a challenge. In some cases, renovations aimed to solve the damages produced by continuous earthquakes and volcanic eruptions. Moreover, loss was often the occasion to rebuilt, to demolish some parts or to abandon sectors due to the lack of economic resources [12].

There is no official scientific documentation of the construction and subsequent interventions of the Jesuitic temple. Modifications were made by the religious order to highlight the image of the temple. However, the research studies focused on both the adobe, brick and stone masonry in the Monastery of San Francisco [13] and the mural painting in the Santo Domingo Convent [14] strengthened the criteria of this study.

The construction of the Jesuitic temple began at the beginning of the 17th century and lasted 160 years. There were three constructive phases. The first phase took place between 1606 and 1636 (Figure 2) and was led by the full order under Father Martin de Azpitarte and Jesuit Gil de Madrigal with an official standard Jesuitic style. The second phase, between 1636 and 1689, was led by Marcos Guerra S.J., a Neapolitan architect who provided visual and spatial unity, proportion and baroque details in the temple [15]. In the third phase, between 1689 and 1765, with the participation of Leonardo Deubler and Venancio Gandolfi, the stone façade of the church was finished (1723-1765). The reading of the church and its adjoining buildings, such as college and university cloisters, was finally consolidated [16]. 


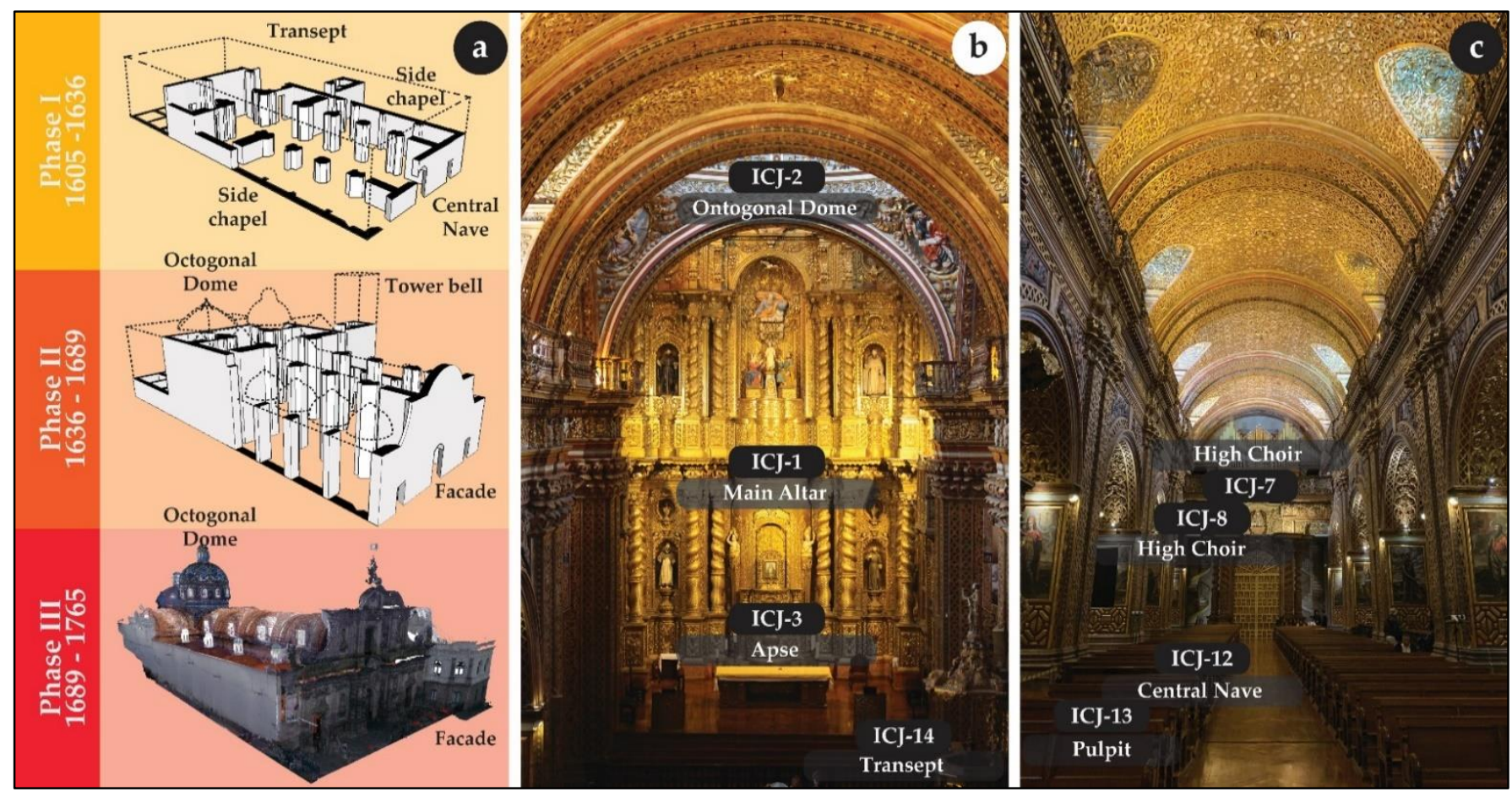

Figure 2. (a) Illustration of the three phases (during a period of 160 years) of the construction process of the Church of the Company of Jesus in Quito: Phase I (1605-1636), construction of the central nave and side chapels; Phase II (1636-1689), construction of the sacristy, the high choir, and the tower; Phase III (1689-1765), the works of the stone façade are finished. (b) Photograph from the central nave to the Main Altar, including the locations where the mortar samples were taken: ICJ-1 sample was taken behind the Main Altar of the central nave; ICJ-2 sample was taken in the octagonal dome; ICJ-3 sample was taken in the lower wall of the apse; ICJ-13 sample was taken in the column start of the pulpit, and ICJ-14 sample in the lower wall of the transept. (c) Photograph from the central nave to the side chapel and choir with the locations where the mortar samples were taken: ICJ-4 sample was taken behind the Calvary Altarpiece; ICJ-5 sample was taken in the lower part of the Calvary Altarpiece; ICJ-6 sample was taken behind the San Jose Altarpiece; ICJ-7 sample was taken in the back of the high choir; ICJ-8 sample was taken in the balustrade of the high choir; and ICJ-12 sample was taken in the column start, ground floor below the choir at the central nave.

It is worth mentioning that, since the construction of the temple until our days, the city of Quito has been affected by tectonics and earthquakes of great intensity, particularly the one of 1755 known as the "earthquake of Quito", which collapsed the novitiate cupola and its roofs and damaged the masonry of the central nave.

After these construction phases, some exceptional events occurred, including the abandonment due to expulsion of the Jesuitic order led by King Carlos III of Spain in 1767. Another moment led by José María Urvina took place in 1852 [17,18]. In this regard, another determinant moment took place when the Jesuitic order gained force between 1862 and 1920; nevertheless, the earthquakes preyed on the temple, thus collapsing the bell tower, and damaging the central nave masonry in 1859. Afterwards, the masonry elements and the roof of the church got more damaged because of the earthquake of 1868 .

In the 20th century, the most critical moment constituted the damages occurred in 1945 when, after a pressure washing of water and sand, the façade lost its treatment of "Venetian luster" that imitated marble. Moreover, cracks and fissures appeared in the masonry, arches, cupolas, and domes in 1987; then, a negligence in 1996 caused a fire in the San Francisco Javier altarpiece when doing internal maintenance works [19]. Finally, in 1998, fissures and cracks were evident in the masonry, cupolas, and domes [3,20-22].

In Ecuador there are few research works about material characterization or heritage mortars $[13,14]$, whose characteristics depend on the construction period, constructional techniques, geographic location, and type of masonry. This study focused on 
the type of mortars used, dosage, compositions and textures; this is how the protocol based on the European standard to extract heritage samples was used [23]. The coatings used on the heritage construction are highly valued and historically important, so its composition, dosage, and chemical, physical and mechanical structure were determined $[24,25]$. The characterization of these mortars could be used to validate the historical sequential chronology described. Thus, the mortars composition gave us the guidelines to restore and conservate [26] this asset and to evaluate future interventions on these constructive elements.

The Real Audiencia de Quito (Royal Court) established the limestone mines where the Jesuitic order extracted the aggregate. Navarro described that the Tanlagua's limestone mine $[10,16]$, the current zone of San Antonio de Pichincha, is home to the Pululahua volcano. This volcano belongs to the Upper Pleistocene-Holocene geological stage [27], which identifies a subvolcanic era as evidenced by the geochemical tests carried out by the Andrade's study: this study showed that the chemical composition of magma has scarcely varied, only stressing a slight impoverishment in the content of Silica, Acid Andesite [28,29].

This work is aimed to identify technically the mineralogical composition of the mortars used in the construction of the Church of the Company of Jesus in Quito, thus improving the intervention level in this building or in those with the same typology, constructive period, and heritage value. This work is part of a broader research project in which the physical-mechanical and application properties of both historical mortars and new intervention materials will be determined.

\section{Materials and Methods}

\subsection{Materials}

In this work, 14 mortar samples were taken and analysed but 11 were chosen for this study (Figure 3). These samples were extracted from the Church of the Company of Jesus by following the indications of the technicians of the temple regarding the places that presumably were not altered in the restoration phases. To take the samples, three sectors were identified according to the construction phases:

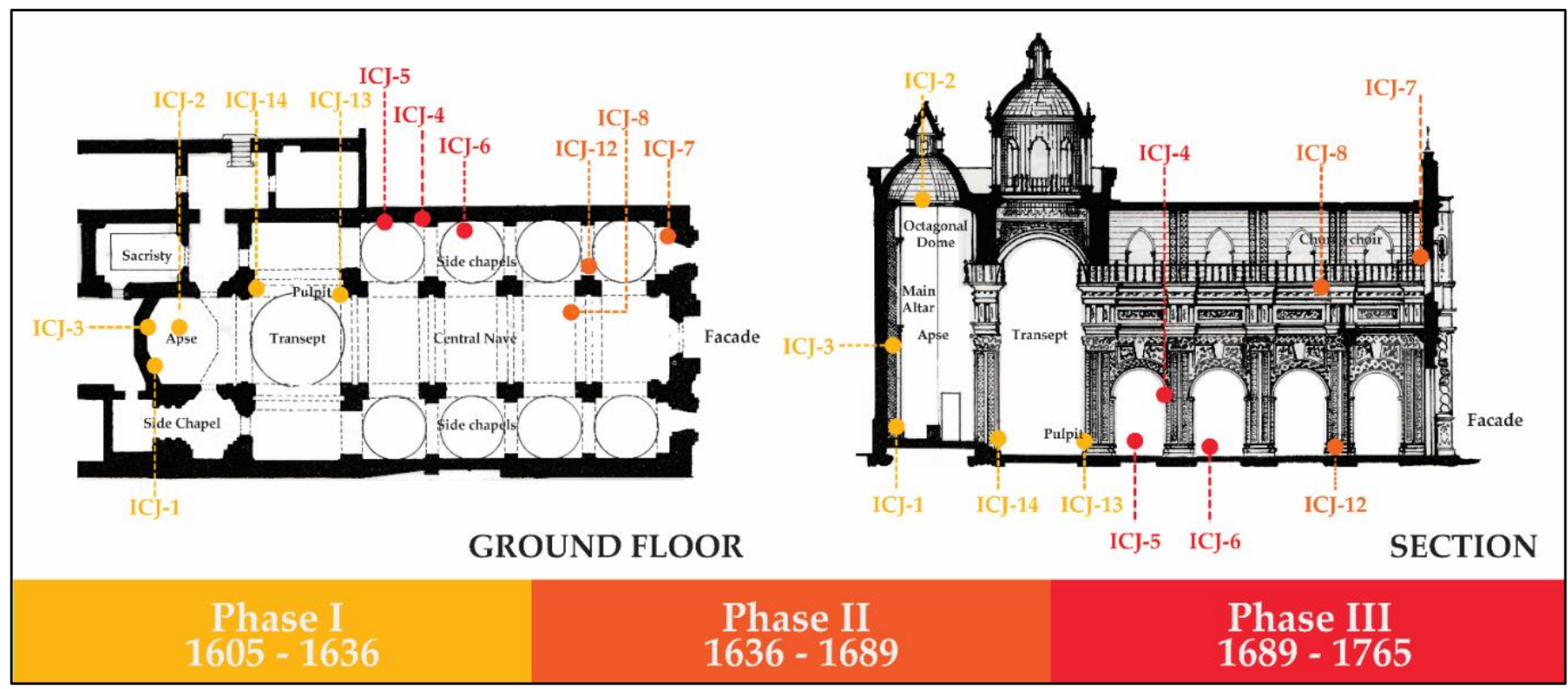

Figure 3. Illustration of both the Plan and Section of the Church of the Company of Jesus in Quito and the locations of the samples analysed. 
Phase I (1606-1636), samples ICJ-1, ICJ-2, ICJ-3, ICJ-13, and ICJ-14. Samples 1, 2 and 3 were extracted behind the Main Altar at different heights: in the middle area, in the cupola and in the lower zone, respectively. Sample 14 was taken in the front start of the column of the transept, and sample 13 in the lower part of the pulpit.

Phase II (1636-1689), samples ICJ-7, ICJ-8, and ICJ-12. Samples 7 and 8 were extracted in the choir, and sample 12 in the lower zone of the right-side chapel.

Phase III (1689-1765), samples ICJ-4, ICJ-5, and ICJ-6. Samples 4, 5 and 6 were extracted in the back of the Calvary and Saint Joseph altarpiece, particularly in the lower part of the right-side chapel.

Additionally, a sample of masonry stone (ICJ-10) was taken as a reference of the possible original source of the crushing aggregates presented in the mortars analysed. Figure 3 shows the location plan of the samples.

\subsection{Methods}

The methodology was based on a systematic process that began with the visual positioning given by the historical and constructive analysis of the place where the samples were taken. Afterwards, the taking of the samples under non-invasive protocols focused on archaeometric analyses to identify and characterize the samples, thus following the same process carried out by the Geological Techniques Unit of the Research Support Centre in Earth Sciences and Archaeometry of the Complutense University of Madrid (Spain) $[24,30,31]$

For both the X-ray diffraction identification and the mineralogical and chemical characterization of samples, these were previously prepared [32,33]. A representative portion of each mortar was fully ground in an agate mortar and sieved to $53 \mu \mathrm{m}$.

The mineralogical identification was carried out by X-ray diffraction (XRD) in a diffractometer Bruker D8 ADVANCE with Cu radiation. Disoriented powder diffraction patterns were obtained in an angular interval between 2 and $65^{\circ}$, a step size of $0.02^{\circ}$, and time per step of $1 \mathrm{~s}$. The relative proportions of each mineralogical phase were identified and determined by following the Chung method (1975) [34] and by using the software EVA of Bruker. The experimental error of this method is plus or minus five percent.

For the morphological and textural study, the most significant samples of each constructive phase were selected: ICJ-1, ICJ-13, and ICJ-14 in Phase I, ICJ-7 in Phase II, and ICJ-4 and ICJ-5 in Phase III. For the morphological and chemical study using a scanning electron microscope (SEM-EDX) [35], the samples were studied in fracture. The scanning electron microscope used was JEOL JSM-820, with secondary and backscattered electron detector and microanalysis. The software used by the team for the acquisition, treatment, and evaluation of the analyses was EDX Oxford ISIS-Link.

\section{Results}

Table 1 shows the results of the mineralogical identification and semi-quantification $( \pm 5 \%)$ carried out by XRD of the samples grouped chronologically.

Based on the mineralogical identification carried out by XRD, optical microscopy (polished section) and petrographic microscopy (thin section). All the analytical bat-tery allowed a qualitative understanding of the type and function of the mortars.

The type of mortars found in the three constructive phases are summarized in Table 2. 
Table 1. XRD mineralogical identification and quantification. The symbols used for the mineralogical phases are according to [36]. Quartz $=\mathrm{Qz}$, Plagioclase group $=\mathrm{Pl}, \mathrm{K}$-feldspar $=\mathrm{Kfs}$, Illite group $($ ClayMinerals $)=$ Ilt, Amphibole group $=$ Amp, Cordierite $=\mathrm{Crd}$, Calcite $=$ Cal, Aragonite $=$ Arg, Fairchildite $=$ Fc, Siderite $=$ Sd, Gypsum $=$ Gp, and Kaolinite $=$ Kln .

\begin{tabular}{|c|c|c|c|c|c|c|c|c|c|c|}
\hline Samples & $\overline{Q z}$ & P1 & Kfs & Ilt & Amp & Cal & Arg & $F c$ & $\mathrm{Gp}$ & Other \\
\hline ICJ-10 & 3 & 75 & & 9 & 8 & & & & & $3^{*}$ \\
\hline ICJ-1 & 7 & & & $8^{*}$ & & 25 & 18 & & 42 & \\
\hline ICJ-2 & 4 & 5 & & & & 72 & & & 19 & \\
\hline ICJ-3 & 3 & 70 & & & 7 & 20 & & & & \\
\hline ICJ-13 & 2 & 58 & 6 & 6 & 20 & 8 & & & & \\
\hline ICJ-14 & 5 & 42 & & $8^{\#}$ & & 16 & & & 18 & $11^{* *}$ \\
\hline ICJ-7 & 2 & 64 & & & 10 & 24 & & & & \\
\hline ICJ-8 & 2 & 61 & & & 18 & 19 & & & & \\
\hline ICJ-12 & & 72 & 4 & & 9 & 7 & & & & \\
\hline ICJ-4 & 2 & 50 & & & 24 & 9 & & 15 & & \\
\hline ICJ-5 & 19 & & & $5^{\#}$ & & 23 & & & 53 & \\
\hline ICJ-6 & 2 & 67 & & & 20 & 9 & & & & $2^{* * *}$ \\
\hline
\end{tabular}

Table 2. Type of mortars found in the Church of the Company of Jesus.

\begin{tabular}{|c|c|}
\hline Samples & Mortar \\
\hline ICJ-1 & Lime and gypsum plaster \\
\hline ICJ-2 & Lime and gypsum plaster with carbonate aggregates \\
\hline ICJ-3 & Lime joint mortar with volcanic aggregates \\
\hline ICJ-13 & Lime joint mortar with volcanic aggregates \\
\hline ICJ-14 & Lime joint mortar with volcanic aggregates \\
\hline ICJ-7 & Lime joint mortar with volcanic aggregates \\
\hline ICJ-8 & Lime joint mortar with volcanic aggregates \\
\hline ICJ-12 & Lime joint mortar with volcanic aggregates \\
\hline ICJ-4 & Lime joint mortar with volcanic aggregates and fire evidence minerals \\
\hline ICJ-5 & Lime and gypsum plaster with carbonate aggregates \\
\hline ICJ-6 & Lime joint mortar with volcanic aggregates \\
\hline
\end{tabular}

Figure 4 shows only the most representative X-ray diffraction patterns of each mortar type found in the Church of the Company of Jesus.

Scanning electron microscopy (SEM) was used to know the morphology and the textural relations of the different mineral phases identified by XRD. Two samples, ICJ-1 (Figures 5 and 6) and ICJ-7 (Figure 7), were chosen as representative samples of the two mortar types existing in the Church of the Company of Jesus: a finishing mortar as base for later ornamentation (lime and plaster mortar) and a joint mortar (lime mortar and volcanic aggregates), respectively [37]. 


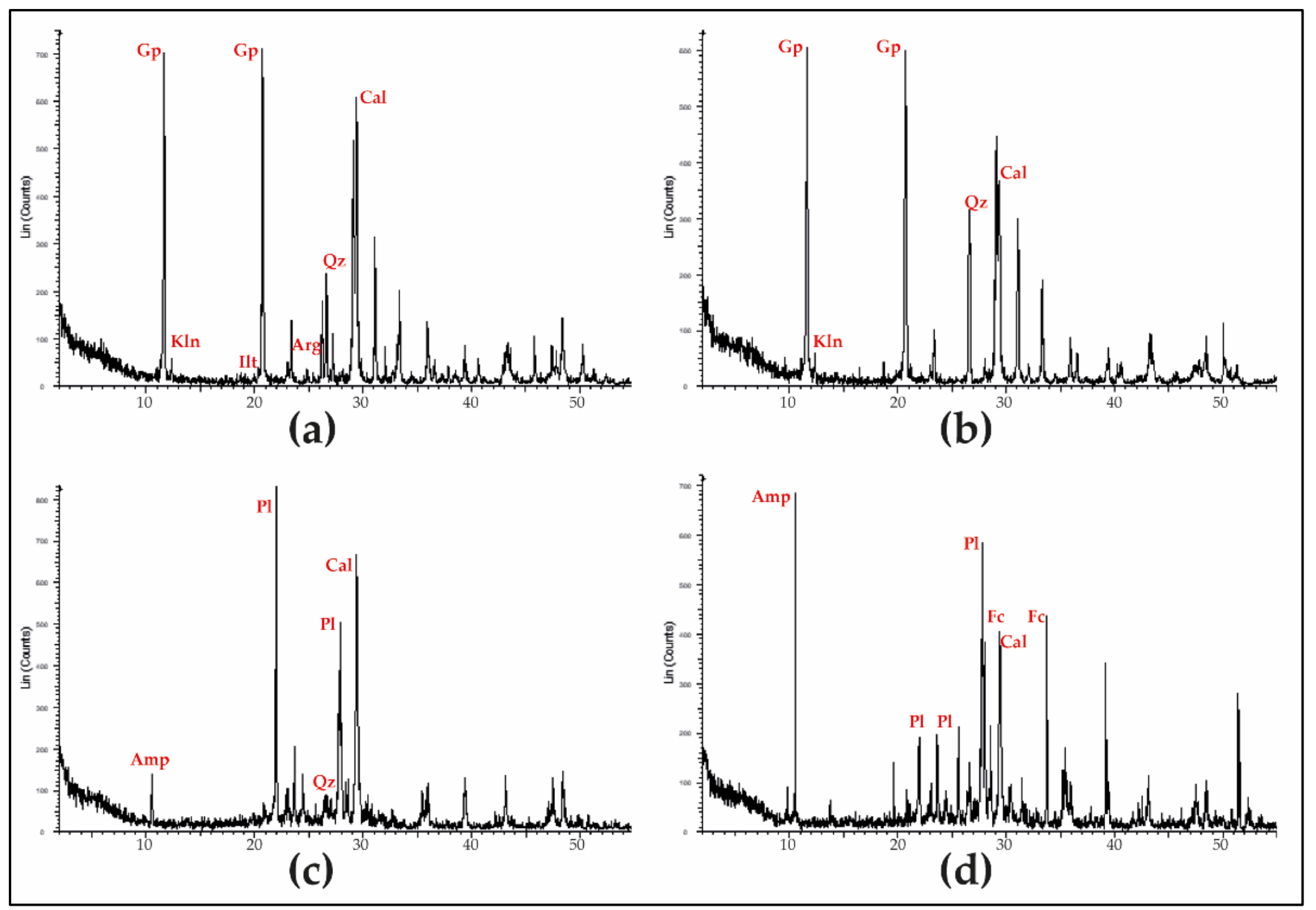

Figure 4. X-ray diffraction patterns of the mortar types: (a) lime and gypsum plaster (ICJ-1); (b) lime and gypsum plaster with carbonate aggregates (ICJ-5); (c) lime joint mortar with volcanic aggregates (ICJ-7); and (d) lime joint mortar with volcanic aggregates and fire evidence minerals (ICJ-4). The main reflection of the mineral identification is printed. Quartz $=$ Qz, Plagioclase group $=$ Pl, Illite group (Clay Minerals) = Ilt, Kaolinite = Kln, Amphibole group = Amp, Calcite $=$ Cal, Aragonite $=$ Arg, Fairchildite $=$ Fc, and Gypsum $=$ G.

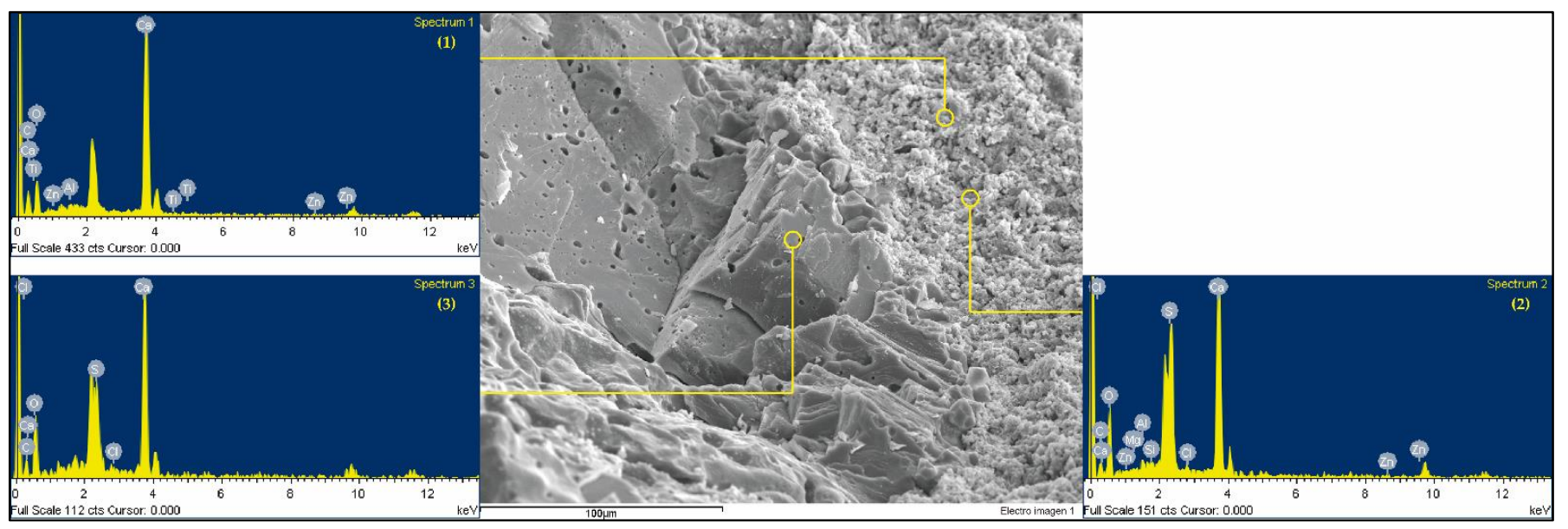

Figure 5. Electron secondary image of lime and gypsum plaster (ICJ-1) with 500 magnifications. EDX analysis at three different points with the main chemical elements: Spectrum 1 with $\mathrm{Ca}, \mathrm{C}, \mathrm{O}$; Spectrum 2 with Ca, S, O; and Spectrum 3 with $\mathrm{Ca}, \mathrm{S}, \mathrm{O}, \mathrm{C}$. 


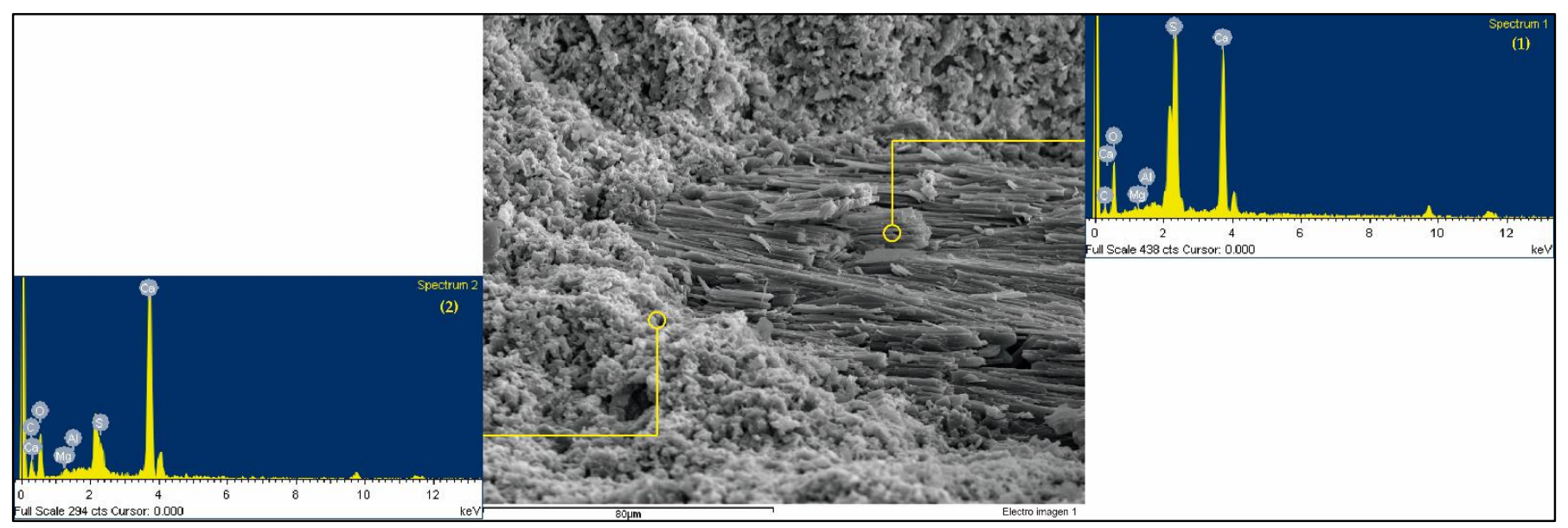

Figure 6. Electron secondary image of lime and gypsum plaster (ICJ-1) with 750 magnifications. EDX analysis at two different points with the main chemical elements: Spectrum 1 with S, Ca, O corresponding to thermoanhydrite no rehydrated to gypsum, and Spectrum 2 with Ca, C, S, O.

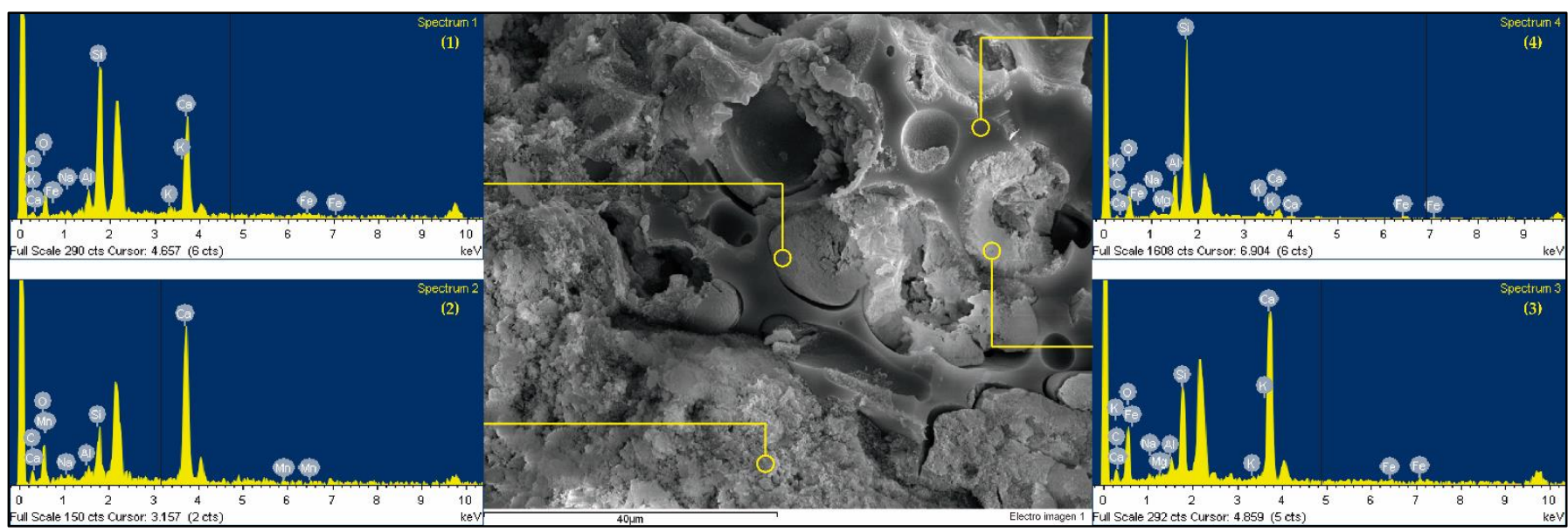

Figure 7. Electron secondary image of lime joint mortar with volcanic aggregates (ICJ-7) with 1500 magnifications. EDX analysis at four different points with the main chemical elements: Spectrum 1 with Si, C, K, O; Spectrum 2 with Ca, Si, K; Spectrum 3 with Ca, Si, K; and Spectrum 4 with Si, Al, C, O.

\section{Discussion}

The identification and characterization of the samples allowed their mineralogy and the several types of current blends to be determined. Thus, a non-ornamental plaster was found in several points of the Church of the Company of Jesus: it was a mixture of lime and gypsum, without added aggregates. This type of material in certain cases supported a final decorative layer.

The combination of gypsum and lime is a mixture that is often seen in historical plasterbased mortars. The lime provides long-term strength and whiteness, and the gypsum gives the mixture workability, volume stability (thus compensating the shrinkage of the lime) and initial strength. This type of mixture is more frequent in the interior of historical masonries where full carbonation is more difficult to achieve and in very irregular masonry walls where a large amount of mortar must be applied [38,39].

Quartz was identified with low proportions in all mortars, between 2 and 7\%, except in sample $5(19 \%)$, and calcite with percentages between 7 and $72 \%$. Quartz was part of the aggregates, and calcite was an aggregate and/or conglomerate according to the type of mortar. The presence of plagioclase and hornblende-type amphibole in many samples should also be stressed: they are main mineral components of the volcanic rock used as an 
aggregate on these mortars, as shown by Hall's research study, which indicated that the rocks that characterize the San Antonio de Pichincha-Pululahua area are "andesite-basaltic (57-60\% $\mathrm{SiO}_{2}$ and $0.5-1.0 \% \mathrm{~K}_{2} \mathrm{O}$ ) with plagioclase and occasionally amphibole" [40].

Sample ICJ-10 showed a mineralogy according to a volcanic rock andesite type, which is a construction material widely used in the temple and in many religious constructions of the Historical Centre of Quito (San Francisco and Santo Domingo) [13,14], and the presence of plagioclase as a main mineral, as well as amphibole, phyllosilicates, quartz and magnetite as secondary minerals. According to SEM observations, aggregates did not show any pozzolanic reaction rings in the interface zone.

The different mineral composition could be associated with building periods of development (Tables 1 and 2). In Phase I, three types of mortars were identified: a lime and plaster lining mortar, a lime and plaster joint mortar with carbonate aggregates, and a lime joint mortar with volcanic aggregates; in Phase II, a single lime joint mortar with volcanic aggregates was identified; and in Phase III, two types of mortars were recognized: a lime lining mortar with carbonate aggregates and a joint mortar with volcanic aggregates (ICJ-4 and ICJ-6).

In ICJ-4 sample Fairchildite has been identified, a double carbonate of potassium and calcium $(\mathrm{K} 2 \mathrm{Ca}(\mathrm{CO} 3) 2)$, which is a mineral associated with woods that suffers combustion processes [31]. In 1996, a fire broke out in the San Francisco Javier altar-piece. This event may explain the presence of this neoformation mineral.

The SEM analysis allowed the origin of the materials used in the church construction to be determined, thus giving value to the hypothesis of the origin of the limestone mines that supplied Quito in the colonial period. Moreover, the effort of the technicians of the Church of the Company of Jesus Foundation was also understood to be faithful to the interventions in this living museum. It is understandable that some materials were replaced to be used, fragmentated or implemented in a vulnerable and seismic area. To use wisely the principles of restoration so as not to alter the building, it should also be noted that the mining catalogue of the Metropolitan District of Quito does not recognize the presence of gypsum mines. Calacali, Pomasqui and San Jose de Minas areas have the extraction of Calcite and Pozzolana as products (Figures 5 and 6).

The main mortar in the church was a lime mortar with volcanic aggregate of glassy texture (Figure 7), which is typical of the basaltic andesite described as the stone used in the construction of the historical centre of Quito $[13,14,41]$. It seems logical that this stone was the origin of the aggregate crushing of the joint mortars in the Church of the Company of Jesus.

This church could have been built by indigenous, mestizos, blacks, and European builders, who applied and merged the European techniques with the local ones $[3,4]$. Using at the same time lime and gypsum mortars and lime mortars with a considerable mineralogical volcanic composition showed the fusion of different constructive cultures.

\section{Conclusions}

The various constructive phases historically transmitted by chroniclers and historians were validated and compared through the sample analysis, thus identifying the compositive elements of each phase. The samples were characterized by both X-ray diffraction (XRD) and scanning electron microscopy with microanalysis (SEM-EDX). In addition, the volcanic origin (Andesites, Dacites) of the materials used in the construction of the church linings was determined. The Pululahua sector destined for limestone mine and belonging to the Jesuit order was the place of extraction of the aggregate. The data obtained from the samples determined common patterns in the components, including Calcite, Plagioclase, Amphibole, Quartz, and Gypsum.

Through the XRD and SEM data, some peculiarities of the constructive periods of the church were identified, and some historical facts of the building that altered the linings were associated, such as the Fairchildite by the effects of high temperatures on wood surfaces in ICJ-4, or the use of Zinc white pigment as finishing on the surfaces of the samples of both 
the pulpit area (as in ICJ-13) and the apse (ICJ-1); these two samples belonged to the oldest phase of the church. Thanks to these data, the construction phases of the church was better understood, and the information provided by Figure 2 was corroborated.

Based on the historical literature, three main construction phases could be discerned. These phases were difficult to visualize in the church given the profuse Baroque decoration.

Finally, mineralogical analyses of the samples with a constructional age contrasted by historical data allowed chronological hypotheses to be established. In addition, three synthetic minerals parageneses were found and traced throughout the church: a general lime mortar and a very characteristic volcanic aggregate with numerous glass vacuoles; a lime mortar and carbonate aggregate with a significant gypsum content; and finally, a lime and gypsum plaster. The lime and gypsum plaster were mainly associated with the first phase. The mortar with volcanic aggregates took place in all the construction phases, and the lime and gypsum mortar with carbonate aggregate corresponded to the first and the third phase. In this case, they could be object of historical repair material.

Author Contributions: For structure, M.L.L.; methodology, M.L.L., D.S.-A. and S.L.-A.; Analytica, D.S.-A. and S.L.-A.; validation, D.S.-A. and S.L.-A.; historical analysis, M.L.L. and I.d.P.; research, M.L.L.; resources, M.L.L.; data curation, M.L.L., D.S.-A., S.L.-A. and I.d.P.; writing — preparation of the original draft, M.L.L., D.S.-A., S.L.-A. and I.d.P.; writing, revision and editing, M.L.L., D.S.-A., S.L.-A. and I.d.P.; translation: M.L.L.; visualization, M.L.L.; supervision, D.S.-A. and S.L.-A.; project administration, M.L.L.; funding acquisition, M.L.L. All authors have read and agreed to the published version of the manuscript.

Funding: This paper is part of the research of the doctoral program in Construction and Architectural Technology DTCA of the Polytechnic University of Madrid whose subject is: "Characterization of the mortar coating of Colonial Quito in the 16th, 17th and 18th centuries". The dissemination of the results of this research stage is financed by International University of Ecuador.

Data Availability Statement: The sources of historical books in this document are primary sources that have not been updated since the middle of the 20th century, some are considered "gray literature", but they serve as a fundamental basis within the qualitative investigation of the present manuscript.

Acknowledgments: Thanks to the openness and easy access and sampling of the church and its authorities of the Church of the Company of Jesus Foundation and the technical personal led by Diego Santander.

Conflicts of Interest: The authors declare that they have no conflict of interest. Funders had no role in the design of the study; in the collection, analysis, or interpretation of data; in the writing of the manuscript or in the decision to publish the results.

\section{References}

1. UNESCO City of Quito. Available online: https://whc.unesco.org/en/list/2/ (accessed on 1 May 2021).

2. Fustillos, A. Encuentro Científico Internacional sobre Ciudades Históricas Iberoamericanas. In San Francisco de Quito; la Mancha, I.-U.C., Ed.; Servicio de publicaciones de la Universidad de Castilla-La Mancha: Cuenca, Spain, 2005; pp. 246-273.

3. Ortiz Crespo, A. Arquitectura Monumental del Centro Histórico de Quito; TRAMA: Quito, Ecuador, 1990; pp. 141-164.

4. Lara, M.L.; Sanz, D.; Del Pino, I. Morteros históricos en las construcciones de Quito de los siglos XVI, XVII y XVIII. Ge-conservacion 2020, 17, 71-81. [CrossRef]

5. Martínez, I.d.P. Centro Histórico de Quito: Una Centralidad Urbana en Transformación Hacia el Turismo. 2001-2008; FLACSO sede Ecuador: Quito, Ecuador, 2009.

6. Patrimonio, I.M. de Diagnóstico del Centro Histórico de Quito. Available online: http:/ /www7.quito.gob.ec/mdmq_ordenanzas /Comisiones del Concejo/Uso de Suelo/Centro Histórico/Información IMP/Plan Parcial Centro Histórico/1. Diagnóstico del CHQ.pdf (accessed on 1 May 2020).

7. Alcalá, L.E. De historias globales y locales: Una aproximación a la historiografía de la arquitectura de los Jesuitas en Hispanoamérica. In La Arquitectura Jesuítica: Actas del Simposio Internacional, Zaragoza, 9, 10 y 11 de Diciembre de 2010; Instituto "Fernando El Católico": Zaragoza, Spain, 2012; pp. 473-496.

8. Navarro, J.G. Arquitectura Americana: La Iglesia de la Compañía de Jesús en Quito; Biblioteca Virtual Miguel de Cervantes: Alicante, Spain, 2011.

9. Jouanen, J. Historia de la Compañía de Jesús en la Antigua Provincia de Quito: 1570-1773, Tomo II 2005; Biblioteca Virtual Miguel de Cervantes: Alicante, Spain, 2005; p. 787. 
10. Jouanen, J. Historia de la Compañía de Jesús en la Antigua Provincia de Quito 1570-1774; Editorial Ecuatoriana: Quito, Ecuador, 1941; pp. 1570-1696.

11. Samaniego, D.D. Diccionario arquitectónico de Quito. In Quito Museos del Banco Cent; Museos del Banco Central del Ecuador Quito: Quito, Ecuador, 1983; p. 54.

12. Martínez, I.d.P.; Yepes, H. Apuntes para una historia sísmica de Quito. In Centro Histórico de Quito: Problemática y Perspectivas, Serie Quito; Junta de Andalucía, Municipio de Quito: Quito, Ecuador, 1990; pp. 67-100.

13. Moropoulou, A.; Polikreti, K.; Ruf, V.; Deodatis, G. San Francisco Monastery, Quito, Equador: Characterisation of building materials, damage assessment and conservation considerations. J. Cult. Herit. 2003, 4, 101-108. [CrossRef]

14. Beltrán, J.; De Vuyst, P.; Rosero, M. Conservación del Patrimonio Artístico del Convento de Santo Domingo; Ecua-bel, P., Ed.; Libri Mund: Quito, Ecuador; Ediciones Libri Mundi: Madrid, Spain, 1994; Volume 6, ISBN 9978-57-014-4.

15. Santander, D.G. Un templo vivo. Sentido y misión de la restauración del templo y Colegio de los jesuitas en Quito. In Radiografía de la Piedra; FONSAL Fondo de Salvameno de Quito: Quito, Ecuador, 2008; pp. 309-337. ISBN 978-9978-36-603-5.

16. Navarro, J.G. Artes Plásticas Ecuatorianas; Fondo de Cultura Económica: Madrid, Spain, 1945; p. 25.

17. Moreno Egas, J. Radiografía en la Piedra: Los Jesuitas y su Templo en Quito, 17th ed.; FONSAL-Fondo de Salvameno de Quito: Quito, Ecuador, 2008; ISBN 978-9978-36-603-5.

18. Piñas Rubio Francisco, S.I. El Arquitecto Hermano Marcos Guerra S.J. y su Obra; Biblioteca Virtual Miguel de Cervantes: Alicante, Spain, 2008.

19. Micó Buchón, J.L. La iglesia de la Compañía de Quito; Fundación Pedro Arrupe, Residencia de San Ignacio: Quito, Ecuador, 2003; ISBN 9978427023.

20. Ospina, P. Dos personales y una perspectiva de la arquitectura y el urbanismo n la Colonia. In Arquitectura de Quito: Una Visión Histórica de su Arquitectura; España, D., Ed.; TRAMA: Quito, Ecuador, 1993; pp. 91-114.

21. D’Ercole, R.; Metzger, P. Los Lugares Esenciales del Distrito Metropolitano de Quito; Colección Quito Metropolitano: Quito, Ecuador, 2002; ISBN 9978-970-45.

22. Escudero Albornoz, X. Escultura Colonial Quiteña: Arte y Oficio-Ximena Escudero-Albornoz-Google Libros; TRAMA: Quito, Ecuador, 2007; ISBN 9978-300-40-6.

23. Comité técnico AEN/CTN 41 UNE-EN 16085. Conservación del Patrimonio Cultural. Metodología para la Toma de Muestras de Materiales del Patrimonio Cultural; UNE: Madrid, Spain, 2014.

24. Veiga, M.R.; Aguiar, J.; Silva, A.S.; Carvalho, F. Methodologies for characterisation and repair of mortars of ancient buildings. In Proceedings of the 3rd International Seminar Historical Constructions, Guimarães, Portugal, 7-9 November 2001 ; pp. 353-362.

25. Válek, J.; Hughes, J.J.; Bartos, P. Compatibility of historic and modern lime mortars. In Proceedings of the 12th International Brick/Block Masonry Conference, Madrid, Spain, 25-28 June 2000; p. 1839.

26. Alonso-Olazabal, A.; Ortega, L.A.; Zuluaga, M.C.; Ponce-Antón, G.; Echevarría, J.J.; Fernández, C.A. Compositional characterization and chronology of roman mortars from the archaeological site of arroyo de la dehesa de velasco (Burgo de osma-ciudad de osma, Soria, Spain). Minerals 2020, 10, 393. [CrossRef]

27. Pacheco, D.; Andrade, D.; Alvarado, A. Estratigrafía Cuaternaria de la Cuenca San Antonio de Pichincha. Rev. Politéc. 2014, 33, $1-9$.

28. Andrade, S.D.; Martin, H.; Monzier, M. Restricciones y un posible modelo para la génesis de los magmas del volcán Pululahua (Ecuador). Rev. Politéc. 2014, 33, 1-13.

29. Viteri, F. Estudio de zonificación territorial de las zonas de explotación de materiales de construcción en el municipio del Distrito Metropolitano de Quito. In Canteras Escuelas en Iberoamerica; Composicáo e Execuáo Gráfica, Ed.; CYTED-CETEM: Río de Janeiro, Brazil, 2001; pp. 87-98.

30. Martinet, G.; Quenee, B. Proposal for a useful methodology for the study of ancient mortars. In Proceedings of the International RILEM Workshop on Historic Mortars: Characteristics and Tests, Paisley, UK, 12-14 May 1999.

31. Martínez, T.L.; García, M.R.B.; Bueno, A.G. Metodología para el estudio de morteros arqueológicos de revestimiento. Geconservacion 2021, 19, 31-44. [CrossRef]

32. Allen, G.C.; Hallam, K.R.; Radonjic, M.; Elton, N.J.; Farey, M.; Ashurst, J. X-ray diffraction and enviromental electron microscopy of hydrated limes. In Proceedings of the International RILEM Workshop on Historic Mortars: Characteristics and Tests, Paisley, UK, 12-14 May 1999; pp. 207-215.

33. Middendorf, B.; Baronio, G.; Callebaut, K.; Hughes, J. Chemical-mineralogical and physical-mechanical investigations of old mortars. In Proceedings of the International RILEM Workshop on Historic Mortars: Characteristics and Tests, Paisley, UK, 12-14 May 1999; pp. 55-62.

34. Chung, F.H. Quantitative interpretation of X-ray diffraction patterns of mixtures. III. Simultaneous determination of a set of reference intensities. J. Appl. Crystallogr. 1975, 8, 17-19. [CrossRef]

35. Ampatzioglou, E.; Karatasios, I.; Colston, B.; Watt, D.; Kilikoglou, V. Lime-Natura Pozzolan Conservation Mortars: Parameter that Affect Reactivity and Strength. In HMC 2010 and RILEM TC 203-RHM Final Workshop, Proceedings of the $2 n d$ Conference on Historic Mortars, Prague, Czech Republic, 22-24 September 2010; RILEM Publications SARL: Prague, Czech Republic, 2010.

36. Whitney, D.L.; Evans, B.W. Abbreviations for names of rock-forming minerals. Am. Mineral. 2010, 95, 185-187. [CrossRef]

37. Carran, D.; Hughes, J.; Leslie, A.; Kennedy, C. A Short History of the Use of Lime as a Building Material beyond Europe and North America. Int. J. Archit. Herit. 2012, 6, 117-146. [CrossRef] 
38. Rodríguez-Navarro, C. Binders in historical buildings: Traditional lime in conservation. Semin. SEM 2012, 9, 91-112.

39. Böke, H.; Akkurt, S.; Ipekoğlu, B.; Uğurlu, E. Characteristics of brick used as aggregate in historic brick-lime mortars and plasters. Cem. Concr. Res. 2006, 36, 1115-1122. [CrossRef]

40. Hall, M.L.; Samaniego, P.; Le Pennec, J.L.; Johnson, J.B. Ecuadorian Andes volcanism: A review of Late Pliocene to present activity. J. Volcanol. Geotherm. Res. 2008, 176, 1-6. [CrossRef]

41. Ortiz Crespo, A. Desde la primera piedra hasta la expulsión: 160 años de historia constructiva. In Radiografía de la Piedra: Los Jesuitas y su Templo en Quito; FONSAL—Fondo de Salvamento de Quito: Quito, Ecuador, 2008; pp. 173-210. ISBN 978-9978-36-603-5. 